\title{
Iklim Kerja Organisasi \\ (Studi pada Dinas Sosial Kabupaten Minahasa)
}

\author{
Abdul Rahman Dilapanga \\ FIS UNIMA \\ Prodi ilmu administrasi negara \\ Tondano, Indonesia \\ abdulrahmandilapanga@unima. \\ ac.id
}

Abstrak - Adapun tujuan penelitian ini dibagi atas tujuan umum dan tujuan khusus sebagai berikut : (1) Mendeskripsikan dan menganalisis tentang iklim kerja organisasi pada Dinas Sosial Kabupaten Minahasa, Mendeskripsikan dan mengalisis tentang faktorfaktor yang mempengaruhi iklim kerja organisasi Dinas Sosial Kabupaten Minahasa.

Penelitian ini menggunakan metode kualitatif yang bertempat di Dinas Sosial Kabupaten Minahasa dan menghasilkan bahwa kualitas kehidupan kerja dan iklim organisasi di Dinas Sosial Kabupaten Minahasa menjadi sangat penting karena hal tersebut berhubungan dengan hasil akhir positif organisasional yang lain dan Yang memperaruhi factor iklim kerja di Dinas Sosial Kabupaten Minahasa adalah sebagai berikut Manajer/pimpinan, Tingkah laku karyawan, laku kelompok kerja, Faktor eksternal organisasi

Kata kunci: Iklim Kerja, Organisasi, Dinas Sosial

\section{PENDAHULUAN}

Iklim organisasi adalah lingkungan manusia dimana para pegawai dalam suatu organisasi melakukan pekerjaan mereka. Pengertian ini dapat mengacu pada lingkungan suatu departemen unit perusahaan atu suatu organisai secara keseluruhan. Menyadari bahwa dalam suatu organisasi sering terjadi interaksi sesama pegawai baik itu antar pimpinan dan bawahan maupun pimpinan dengan pimpinan dalam suatu organisasi. Dalam setiap organisasi memiliki iklim kerja yangberbeda-beda, ada suasana kondusif, dinamis, sementara yang lan kurang bahkan tidak kondusif. Hal ini dipengaruhi factor internal pegawai, iklim organisasi itu dan lingkungan eksternal organisasi. Perpaduan antara lingkungan internal dan pelaksanaan peran pada akhirnya mempengaruhi aktivitas, kepuasan, dan pertumbuhan organisasi baik buruknya iklim organisasi dapat menyebabkan perubahan perilaku pegawai menjadi negatif atau positif. Pengaruh posotof dapat menimbulkan perubahan kea rah perbaikan, dalam hal ini pengingkatan kinerja yang ada pada akhirnya dapat tercapai tujuan oganisasi. Sedangkan pengaruh negative 
membawa pengaruh pada kinerja pegawai yang dapat menimbulkan keterlambatan, kemungkinan turnover pegawai bahkan kesengajaan memperlambat kerja.

Menciptakan sebuah iklim organisasi yang mampu membawa para anggotanya untuk meningkatkan prestasi dalam rangka pencapaian tujuan organisasi bukanlah suatu hal yang mudah. Hal ini disebabkan karena pada dasarnya manusia memiliki karakteristik tingkah laku yang berbeda sesuai dengan tingkat kebutuhannya. Apabila terdapat perbedaan atau kesenjangan antara persepsi anggota dengan persepsi pimpinan mengenai iklim yang dirasakan dan yang diharapkan, maka ini akan memungkinkan terciptanya ketidakpuasan kerja dari anggota, sehingga dapat menimbulkan penyalahgunaan hak dan kewajiban yang akhirnya mengakibatkan tujuan organisasi tidak dapat dipenuhi secara optimal. Persoalan-persoalan ini semakin bertumpuk dengan kecenderungan organisasi untuk berkembang, dan menyesuaikan diri dengan perkembangan lingkungan di sekitarnya sehingga angota seringkali kehilangan identitas pribadi, dan pimpinan makin sulit untuk memuaskan kebutuhan angota dan mencapai tujuan organisasi sekaligus. Suatu organisasi akan mengalami perubahan organsasional dan perencanaan sumber daya manusia (SDM). Hal ini berarti bahwa setiap organisasi harus selalu peka terhadap kekuatan lingkungan yang mempengaruhi organisasi. Perkembangan organisasi menuntut adanya iklim organisasi yang kondusig. Pines seperti dikutip oleh Barkah (2002: 35) menyatakan bahwa iklim kerja sebuah organisasi dapat diukur melalui empat dimensi sebagai berikut yaitu: dimensi psikologi, dimensi social, dimensi structural, dan dimensi birokrat. Dimensi psikologi maksudnya iklim organisasi yang baik dapat dilihat dari tingkah laku setiap orang yang baik dalam organisasi. Dimensi social maksudnya iklim organisasi yang baik dapat dilihat dari hubungan atau kerja sama yang baik setiap angotanya. Dimensi struktural maksudnya iklim organisasi yang baik dapat dilihat dari penataan susunan organisasi secara rapi, dimensi birokrat maksudnya iklim organisasi yang baik dapat dilihat dari prosedur kerja dalam roda organisasi. Oleh karena itu suatu organisasi memang harus mempunyai tujuan, agar roda organisasi itu berjalan dengan lancer dan terarah. Dan dari uraiaan di atas menunjukan bahwa iklim organisasi, sangat penting dalam menentukan kinerja organisasi.

Dinas Sosial Kabupaten Minahasa merupakan salah satu Satuan Kerja Perangkat Daerah (SKPD) yang melaksanakan kewenangan tugas, diharapkan memiliki iklim organisasi yang kondusif, sehingga dapat memberikan pelayan (pelayanan publik) kepada masyarakat yang berada di provinsi ini. Akan tetapi kenyataan menujukan bahawa iklim organisasi blum seprti yang diharapkan, hal ini diindikasikan dengan masih adanya budaya (kultur) kerja yang kurang kondusif dimana masih ada staf yang berperilaku kurang simpatik dalam memberikan pelayanan 
kepada masyarakat, adanya persaingan yang tidak sehat antara sesame staf yang menimbulkan konflik sehingga kinerja yang ditunjukan tidak optimal. Indicator lainnya adalah penempatan staf pada bidang yang tidak sesuai dengan kompetensi yang dimiliki pada struktur organisasi, sehingga yang bersangkutan tidak optimal dalam melaksanakan pekerjaan dan pelayanan kepada masyarakat, kurangnya reward yang diberikan kepada staf yang telah menunjukan kinerja yang baik berupa promosi jabatan, kurangnya pemberdayaan staf dan berbagai indicator lainnya.

Dari uraian yang dikemukakan di atas, maka iklim organisasi Dinas Sosial Kabupaten Minahasa, dilihat dari sisi sumber daya manusianya, kelemahan utamanya adalah berkaitan dengan profesionalisme, kompetensi, empathy dan etika, masalah system kompensasi dan pemberian utama terletak pada disain oraganisai yang tidak dirancangn khusus dalam rangka pemberian pelayanan kepada masyarakat, penuh dengan hirarki yang membuat pelayanan menjadi berbelit-belit (birokratis), dan tidak terkoordinasi. Kecenderungan untuk melaksanakan dua fungsi sekaligus, fungsi pengatuarn dan fungsi penyelenggaraan, masih sangat kental dilakukan yang juga menyebabkan pelayanan kepada masyarakat menjadi tidak efisien.

Berdasar paparan yang dikemukakan di atas, peneliti tertarik untuk mengadkan penlitian yang berjudul: "Iklim Kerja Organisasi Dinas Sosial Kabupaten Minahasa".

\section{METODE PENELITIAN}

Metode penelitian yang digunakan dalam penelitian ini adalah metode kualitatif deskriptif. Seperti yang digunakan Sugiyono (2014:8) bahwa metode penelitian kualitatif disebut sebagai metode penelitian naturalistik karena penelitiannya dilakukan di kondisi yang ilmiah

\section{HASIL DAN PEMBAHASAN}

Hasil penelitian menunjukkan bahwa ada hubungan positif yang sangat signifikan antara iklim organisasi dengan kualitas kehidupan kerja karyawan Dinas Sosial Kabupaten Minahasa. Berdasarkan hasil tersebut, hipotesis yang diajukan pada penelitian ini diterima. Hal ini mengindikasikan bahwa semakin positif iklim organisasi maka semakin tinggi kualitas kehidupan kerja pada karyawan. Sebaliknya, semakin negatif iklimorganisasi maka semakin rendah kualitas kehidupan kerja pada karyawan.

Kualitas kehidupan kerja adalah kesejahteraan fisik dan psikologis karyawan dalam bekerja yang secara relatif merasa puas dan mendapat kesempatan mampu tumbuh dan berkembang selayaknya manusia. Riady (2009) menekankan bahwa paradigma kualitas kehidupan kerja berfokus pada persoalan seperti motivasi, keterlibatan karyawan dan kepuasan kerja.

Kualitas kehidupan kerja dapat meningkatkan efisiensi dan efektifitas organisasi dengan memberikan kontribusi terhadap transformasi sumberdaya, inovasi, dan daya 
adaptasi. Bila kualitas kehidupan kerja pada karyawan menunjukkan prosentasi yang tinggi, makaakanmenimbulkan dampak positif bagi organisasi, seperti meningkatnya produktivitas, kualitas kerja, dan menurunkan tingkat absenteeism dan turn over (Riggio, 1990). Namun sebaliknya bila kualitas kehidupan kerja karyawan pada perusahaan rendah, maka tidak akan terjadi peningkatan produktivitas kerja karyawan. Kualitas kehidupan kerja tentu saja merupakan tujuan bagi semua perusahaan dan institusi yang mempekerjakan karyawan, sebab kualitas kehidupan kerja karyawan ini pada akhirnya diharapkan dapat meningkatkan produktivitas perusahaan secara keseluruhan.

Data hasil penelitian ini membuktikan bahwa salah satu faktor yangmempengaruhi kualitas kehidupan kerja pada karyawan Dinas Sosial Kabupaten Minahasa adalah iklim organisasi. Perbedaan persepsi terhadap iklim organisasi yang disebabkan dari beberapa kondisi (diantaranya; bagaimana setiap orang mempersepsi aturan-aturan, kebijakan-kebijakan, dan prosedur-prosedur organisasi terutama masalah-masalah yang berhubungan dengan personalia, distribusi imbalan, gaya komunikasi, cara-cara yang digunakan untuk memotivasi, teknik-teknik dan tindakan pendisiplinan, interaksi antara menajemen dan kelompok, interaksi antara kelompok, perhatian pada permasalahan yang dimiliki karyawan dari waktu ke waktu) dengan sendirinya memberi pengaruh yang berbeda pada kualitas kehidupan kerja. Persepsi positif karyawan terhadap lingkungan kerjanya dapat menimbulkan perasaan senang, gembira dan penuh percaya diri terhadap pekerjaan dan tanggung jawabnya, oleh karena itu persepsi tersebut dapat mempengaruhi kualitas kehidupan kerja karyawan. Sebaliknya, jika karyawan memiliki persepsi negatif terhadap lingkungan organisasinya, maka mereka akan merasakan pekerjaan sebagai suatu beban, yang akhirnya akan menurunkan kualitas kehidupan kerja mereka.

Hasil penelitian ini mendukung pendapat dari Dessler (1992) yang menyatakan bahwa kemampuan untuk mewujudkan kualitas kehidupan kerja pada diri sendiri bergantung pada apakah terdapat adanya perlakuan yang adil dan suportif para pegawai, kesempatan bagi tiap pegawai untuk menggunakan kemampuan secara penuh, kesempatan untuk mengembangkan diri, komunikasi terbuka dengan saling mempercayai diantara rekan kerja, kesempatan bagi semua pegawai untuk berperan secara aktif dalam pengambilan keputusan penting yang melibatkan pekerjaan mereka, kompensasi yang cukup adil dan lingkungan yang sehat dan aman. Kesemua itu didapat dari bagaimana karyawan mempersepsinya berdasar kebutuhan dan sistem nilai yang ada dalam masing-masing diri karyawan. Jika kondisi iklim organisasi sebagaimana dipersepsi oleh karyawan baik, maka menurut Umstot (Idrus,2006) akan menghasilkan 
3 katagori psychological states, yaitu (1) kebermaknaan pekerjaan yang dialami; (2) tanggungjawab hasil pekerjaan yang dialami; (3) pengetahuan dari hasil nyata pekerjaan yang dilaksanakan. Bila ketiga kondisi psikologis ini muncul, maka sejumlah kepribadian dan hasil pekerjaan positif dapat diprediksikan. Orang akan merasa lebih baik dengan pekerjaan mereka dan lebih menyukai pekerjaan yang berkualitas tinggi. Dengan sendirinya jika orang telah merasa nyaman dengan pekerjaannya, maka akan meningkatkan kualitas kehidupan kerjanya.

Penelitian ini, mendapatkan bahwa tingkat kualitas kehidupan kerja pada karyawan berada pada kategori tinggi. Kualitas kehidupan kerja yang cenderung positif ini mencerminkan bahwa karyawan memiliki persepsi yang cukup baik terhadap lingkungan perusahaan dan iklim organisasi yang dipengaruhi oleh apa danbagaimana timbal balik yang diperolehnya dari perusahaan. Hal itu diperkuat juga dari hasil wawancara dengan beberapa karyawan. Menurut mereka, perusahaan selalu berusaha memberikan kesempatan untuk belajar. Tidak hanya itu, perusahaan juga memperhatikan kesejahteraan dan memberikan keleluasaan bagikaryawan untuk membina paguyuban (kekeluargaan). Dalam penelitian ini, sumbangan efektif diberikan oleh iklim organisasi terhadap terciptanya kualitas kehidupan kerja karyawan.

Penelitian ini juga mendukung penelitian sebelumnya yang dilakukan Sudarnoto (2001).
Penelitiannya membuktikan bahwa kondisi kualitas kehidupan kerja dapat tercipta apabila kebutuhan pekerjaan atas persyaratan pekerjaan, lingkungan pekerjaan, perilaku pemimpin serta praktek kerja yang memperhatikan kebutuhan personal pekerjaan telah terpenuhi.

Penelitian ini juga senada dengan penelitian yang dilakukan Dhar (2008), tentang kualitas kehidupan kerja. Penelitian yang berkaitan dengan kualitas kehidupan kerja dari supir bus dan faktor yang menyebabkan ketidakseimbangan, yang menyebabkan probabilitas tinggi kecelakaan di jalan. Sebuah studi kualitatif dilakukan dengan bantuan lima belas sopir bus dari empat depot bus yang berbeda Pune Municipal Corporation, India. Wawancara dilakukan secara mendalam dan melalui metode observasi naturalistik, untuk mengumpulkan data. Analisis data dilakukan melalui proses coding. Hasilnya menunjukkan bahwa kualitas kehidupan kerja tidak hanya harus diteliti dalam hal inisiatif yang dirancang untuk meningkatkan kehidupan kerja bagi karyawan. Sebaliknya, ada faktor potensial yang dapat berdampak pada kualitas kehidupan kerja untuk supir, yaitu tantangan yang mereka hadapi selama hari kerja dan kondisi di mana mereka bekerja.

Begitu juga dengan penelitian yang dilakukan Deka (2011) yang menyatakan bahwa ada pengaruh iklim organisasi terhadap organisasi pembelajaran dan kualitas kehidupan kerja yaitu semakin tinggi iklim organisasi maka semakin 
tinggi pula organisasi pembelajaran dan kualitas kehidupan kerja karyawan. Dalam penelitiannya, iklim organisasi memberikan pengaruh sebesar $10,7 \%$ terhadap kualitas kehidupan kerja. Berdasarkan hasil analisis regresi diketahui bahwa secara keseluruhan iklim organisasi memberikan kontribusi terhadap kualitas kehidupan kerjadengan $\mathrm{R}$ square sebesar 0.484 atau $48,4 \%$, dengan demikian iklim organisasi memberikan kontribusi yang besar terhadap kualitas kehidupan kerja dengan sumbangan sebesar 48,4 \%, sedangkan 51,6 \% iklim organisasi dipengaruhi oleh faktor lainnya, misalnya kepemimpinan transformasional, persepsi karyawan terhadap kompensasi, kepuasan kerja, persepsi terhadap kinerja, dan stress kerja.

Factor yang mempengatuhi iklim kerja organisasi di Dinas Sosial Kabupaten Minahasa

\section{a. Manajer/pimpinan}

Pada dasarnya setiap tindakan yang diambil oleh pimpinan atau manajer di Dinas Sosial Kabupaten Minahasa mempengaruhi iklim dalam beberapa hal, seperti aturan-aturan, kebijakan-kebijakan, dan prosedur-prosedur organisasi terutama masalah-masalah yang berhubungan dengan masalah personalia, distribusi imbalan, gaya komunikasi, cara-cara yang digunakan untuk memotivasi, teknik-teknik dan tindakan pendisiplinan, interaksi antara manajemen dan kelompok, interaksi antar kelompok, perhatian pada permasalahan yang dimiliki karyawan dari waktu ke waktu, serta kebutuhan akan kepuasan dan kesejahteraan karyawan.

b. Tingkah laku karyawan

Tingkah laku karyawan di Dinas Sosial Kabupaten Minahasa mempengaruhi iklim melalui kepribadian mereka, terutama kebutuhan mereka dan tindakan-tindakan yang mereka lakukan untuk memuaskan kebutuhan tersebut. Komunikasi karyawan memainkan bagian penting dalam membentuk iklim. Cara seseorang berkomunikasi menentukan tingkat sukses atau gagalnya hubungan antar manusia.

Berdasarkan gaya normal seseorang dalam hidup atau mengatur sesuatu, dapat menambahnya menjadi iklim yang positif atau dapat juga menguranginya menjadi negatif.

c. Tingkah laku kelompok kerja

Terdapat kebutuhan tertentu pada kebanyakan orang dalam hal hubungan persahabatan, suatu kebutuhan yang seringkali dipuaskan oleh kelompok dalam organisasi. Termasuk di Dinas Sosial Kabupaten Minahasa Kelompok-kelompok berkembang dalam organisasi dengan dua cara, yaitu secara formal, utamanya pada kelompok kerja; dan informal, sebagai kelompok persahabatan atau kesamaan minat.

d. Faktor eksternal organisasi

Sejumlah faktor eksternal dari organisasi di Dinas Sosial Kabupaten Minahasa mempengaruhi iklim pada organisasi tersebut. 
Keadaan ekonomi adalah faktor utama yang mempengaruhi iklim. Contohnya dalam perekonomian dengan inflasi yang tinggi, organisasi berada dalam tekanan untuk memberikan peningkatan keuntungan sekurangkurangnya sama dengan tingkat inflasi. Seandainya pemerintah telah menetapkan aturan tentang pemberian upah dan harga yang dapat membatasi peningkatan keuntungan, karyawan mungkin menjadi tidak senang dan bisa keluar untuk mendapatkan pekerjaan pada perusahaan lain. Di lain pihak, ledakan ekonomi dapat mendorong penjualan dan memungkinkan setiap orang mendapatkan pekerjaan dan peningkatan keuntungan yang besar, sehingga hasilnya iklim menjadi lebih positif.

\section{PENUTUP}

Kualitas kehidupan kerja dan iklim organisasi di Dinas Sosial Kabupaten Minahasa menjadi sangat penting karena hal tersebut berhubungan dengan hasil akhir positif organisasional yang lain. Faktor-faktor persepsi dalam iklim organisasi secara langsung dan tidak langsung merefleksikan praktekpraktek yang membuat karyawan memiliki kualitas kehidupan kerja dalam bekerjanya. Kondisi kerja yang buruk, pendapatan yang dinilai tidak memadai dan kurangnya otonomiserta kurangnya stabilitas kerja akan berakibat pada rendahnya kualitas kehidupan kerja seseorang

Yang memperaruhi factor iklim kerja di Dinas Sosial Kabupaten Minahasa adalah sebagai berikut Manajer/pimpinan, Tingkah laku karyawan, laku kelompok kerja, Faktor eksternal organisasi

\section{UCAPAN TERIMA KASIH}

Ucapan terimaksih disampaikan kepada pimpinan FIS Unima yang boleh menyutui rencana pelaksanaan penelitian ini dan kepada Pimpinan LPPM Unima yang sudah Membiayai Penelitian ini sehingga dapat selesai dengan baik. 


\section{REFERENSI}

[1] Dhar, R. L. (2008). Quality of work life: A study of municipal corporation bus drivers. The Journal of International Social Research, 1(5), 251-273.

[2] Dessler, G. (1992). Manajemen personalia teknik dan konsep modern (Penterjemah: Agus Dharma). Jakarta: Erlangga.

[3] Idrus, M. (2006). Implikasi organisasi terhadap kepuasan kerja dan kualitas kehidupa kerja karyawan. Jurnal Psikologi Universitas Diponogoro, 3(1), 94-106.

[4] Riady, H. (2009). Meningkatkan komitmen karyawan atas organisasi melalui pengelolaan "quality of work life". Journal of Human Capital, 1(2), 119-13.
[5] Riggio, R. E. (1990). Introduction to industrial/organizational psychology. New Jersey: Prentice Hall, inc

[6] Sudarnoto, L. F. N. (2001). Faktor-faktor pendukung kualita skehidupan kerja. Disertasi (Tidakditerbitkan). Yogyakarta: Program Psikologi Universitas Gadjah Mada. 